DOI https://doi.org/10.18551/rjoas.2017-10.31

\title{
ENHANCING PRODUCTION AND SALAK SUWARU FARMING INCOME
}

\author{
Sudaryono Tri, Researcher \\ Agricultural Technology Assessment Institute of East Java, Malang, Indonesia \\ E-mail: tri sdr@yahoo.com
}

\begin{abstract}
Salak is an Indonesian indigenous fruit crop and in various areas, Salak is acknowledged as beneficial fruit that has enormous both national and international market opportunities. One of the areas in East Java which is the center of Salak production is Malang Regency known as Salak Suwaru. Salak Suwaru as one of East Java's superior fruit has been released as a superior variety; it has thick flesh meat, masir, sweet, sharp-flavored and its weight between 70-120 g. The efforts to increase production and Salak Suwaru farm income need to be done as perceiving its economic value. This research aims to discover the effect of water supply and ZA fertilization on production and increase Salak Suwaru farm's Income that has been conducted in Suwaru Village, Pagelaran Sub-district, Malang Regency from April 2012 until August 2013. The result shows that the increase of production and Salak Suwaru farm Income can be achieved through water supervision and ZA fertilization. Water supply and ZA fertilization can increase the production of Salak Suwaru up to multiple. Through the water supervision and ZA fertilization, Salak Suwaru farm Income can be increased up to three times.
\end{abstract}

\section{KEY WORDS}

Fertilizer, production, income, salak, water.

Salak is an Indonesian native fruit crop (Mogea, 1984) and in some areas, Salak is acknowledged as beneficial fruit that has enormous both national and international market opportunities (Sumarno, 2004). Salak plants included palm family, first cultivated in Java and fruit marketed in Singapore (Ridley, 1925). Some various areas in Java areas known as the main production center of Salak, therefore Java is known as the center of Salak cultivation. One of the areas in East Java which is the main production center of Salak is Malang Regency known as Salak Suwaru center.

Salak Suwaru as one of East Java's superior fruit has been released as a superior variety through Ministry of Agriculture Decree No: 120/KPTS/TP/240/3/1991. The superiorities of Salak Suwaru are thick meat, ripe, sweet, sharp-flavored and weight per fruit is between $70-120 \mathrm{~g}$ (Widyastuti and Paiman, 1993; Food Crop Agriculture Department Level II Malang Regency, 1997). Currently Salak Suwaru by farmers has been used as well as processed raw materials, namely dodol or jenang and syrup. This fact has instigated the Gondanglegi sub-district to be nominated as the Center for Agribusiness Development of Prime Commodity (SPAKU) with one of its objectives is to grow the Salak agro industry in the area (Regional Office of the Department of Agriculture of the First Level Region of East Java Province, 1999). The growth of agroindustry in SPAKU area is expected to increase the demand of Salak fruit.

Salak plants are diverse from other tropical fruit crops that are generally only once harvest in a year with almost the same time. Salak fruit harvest can occur at least twice a year, once a harvest and once gadu or apitan harvest. The harvest season generally occurs in December until February, while gadu harvest is generally in June to August (Sudaryono et al., 1993).

At certain times, especially in the dry season of Salak plants do not produce flowers, because in the dry season there is no addition of sprout. The absence of new sprout addition instigated due to lack of water and lack of nitrogen and sulfur nutrient input. To support growth and production, Salak plants require sufficient water throughout the year (Schuiling and Mogea, 1992). Nitrogen and sulfur are essential macro nutrients for palm family plants. 
The lack of both nutrients will interpose plant's growth and development (Nethsinghe, 1962, Felizardo, 1983). In order to obtain the production's improvement, especially off-season production, in the dry season of Salak plants required to be irrigated and fertilized with nutrients containing nutrients $\mathrm{N}$ and $\mathrm{S}$. This research aims to discover the effect of water supply and ZA fertilization on the production and Salak Suwaru farmers' improvement Income.

\section{METHODS OF RESEARCH}

The research was conducted in Suwaru Village, Pagelaran Sub-district, Malang Regency from April 2012 until August 2013. This research used a split plot design that was repeated three times. The main plot treatment is water delivery, consisting of no irrigation and irrigation at 20 days intervals. Water delivery is done by leb or 20 liters per tree (Soleh et al., 1995); Wijadi et al., 2000). Irrigation started from April to October 2012, because these months are the dry season. The treatment of subplot is ZA fertilizer dosage consisting of $0 \mathrm{~g}$, $100 \mathrm{~g}, 200 \mathrm{~g}$ and $300 \mathrm{~g}$ ZA per tree. The experiment was conducted in farmer's farm with plant age about 20 years and spacing $2 \mathrm{~m} \times 2 \mathrm{~m}$. Each treatment consists of 10 trees. In addition to fertilized ZA in accordance with the treatment, Salak plants are also fertilized with $37.5 \mathrm{~g}$ Urea $+175 \mathrm{~g} \mathrm{KCl}+200 \mathrm{~g}$ Dolomite $+3.75 \mathrm{~g}$ Borax $+3.75 \mathrm{~g}$ Zinc Sulfate per tree as a base fertilizer. Basic fertilizer is given after harvest time and one month after basic fertilizer application, fertilization is completed with ZA according to treatment.

Data collected by the number of flower clusters, the number of fruit clusters, the number of fruits per cluster, the weight per fruit clusters, as well as the production and farmers' income during apitan harvest, and off-season harvest.

\section{RESULTS AND DISCUSSION}

The Effect of Water Distribution and ZA Fertilization on the Number of Flower Clusters and Fruit Weight per Cluster. Water supply and ZA fertilization affect the number of Salak Suwaru flower clusters. The steadiness of Salak Suwaru flower appears to be highly dependent on soil moisture content. It is indicated that 20 days interval given increases the number of flower clusters two to three times (Table 1).

Table 1 - The Effect of water supply on the number of Salak Suwaru flower clusters per tree

\begin{tabular}{lcccc}
\hline \multirow{2}{*}{ Treatment } & \multicolumn{3}{c}{ the number of flower clusters per tree } \\
\cline { 2 - 5 } & $\begin{array}{c}2 \text { month after } \\
\text { water } \\
\text { application }\end{array}$ & $\begin{array}{c}3 \text { month after } \\
\text { water } \\
\text { application }\end{array}$ & $\begin{array}{c}4 \text { month after } \\
\text { water } \\
\text { application }\end{array}$ & $\begin{array}{c}5 \text { month after water } \\
\text { application }\end{array}$ \\
\hline Without irrigation & $0,60 \mathrm{a}$ & $0,60 \mathrm{a}$ & $0,40 \mathrm{a}$ & $0,50 \mathrm{a}$ \\
20 days interval-irrigation & $1,30 \mathrm{~b}$ & $1,10 \mathrm{~b}$ & $1,20 \mathrm{~b}$ & $1,40 \mathrm{~b}$ \\
\hline
\end{tabular}

Note: The figures in the same column completed by different letters show an obvious difference based on the BNT test at the $5 \%$.

Table 2 - The Effect of ZA fertilization on the number of Salak Suwaru clusters per tree

\begin{tabular}{ccccc}
\hline $\begin{array}{c}\text { ZA fertilizer } \\
\text { dosage } \\
\text { (g/tree) }\end{array}$ & $\begin{array}{c}\text { 2 months after fertilizer } \\
\text { application }\end{array}$ & $\begin{array}{c}\text { 3 months after fertilizer } \\
\text { application }\end{array}$ & $\begin{array}{c}\text { 4 months after } \\
\text { fertilizer } \\
\text { application }\end{array}$ & $\begin{array}{c}5 \text { months after fertilizer } \\
\text { application }\end{array}$ \\
\hline 0 & $0,42 \mathrm{a}$ & $0,50 \mathrm{a}$ & $0,60 \mathrm{a}$ & $0,60 \mathrm{a}$ \\
100 & $0,88 \mathrm{~b}$ & $0,80 \mathrm{ab}$ & $0,90 \mathrm{~b}$ & $1,00 \mathrm{~b}$ \\
200 & $1,23 \mathrm{~b}$ & $1,10 \mathrm{~b}$ & $1,00 \mathrm{~b}$ & $1,00 \mathrm{~b}$ \\
300 & $1,27 \mathrm{~b}$ & $1,00 \mathrm{~b}$ & $0,90 \mathrm{~b}$ & $1,20 \mathrm{~b}$ \\
\hline
\end{tabular}

Note: The figures in the same column completed by different letters show an obvious difference based on the BNT test at the $5 \%$. 
Besides influenced by water content, it seems that the continuity of Salak Suwaru is also influenced by the availability of $\mathrm{N}$ and $\mathrm{S}$ elements. It is shown that the application of ZA fertilizer has an effect on the number of bunches of Salak Suwaru. Suwaru ZA fertilizer plants produce more bunches of flowers than plants that are not fostered ZA (Table 2).

Water is one of the basic needs for plants, including Salak plants. Chapman and Carter (1976) suggested that in living plant tissues containing water 85 to $95 \%$. Salak is a class of plants that required water in large quantities. The amount of water required by Salak is different for each growth phase, where the flowering and fertilization phases of water demand more than the other growth phases (Lestari and Ebert, 2002). Therefore, if the soil is lack of water, especially in the dry season, irrigation is absolutely necessary. This fact indicates that the emergence of Salak Suwaru flowers is obviously due to the availability of water supply at 20-day interval aimed at maintaining the available groundwater content of $85 \%$.

Fertilizers and water are two associated components and are critical to growth and crop yield. The role of water is essential as water serves as a solvent of organic and inorganic substances in the soil (Barber, 1984), photosynthetic feedstock and hydrolysis process (Gardner et al., 1985). Fertilizer application is beneficial for plants when there is sufficient water, therefore the fertilizer can be dissolved (decomposed) into ions and cation that can be absorbed by plants. Soleh et al. (1995) suggested that urea fertilization, ammonia nitrogen, potassium chloride, dolomite, borax and zinc sulfate in Salak plants followed by water supply, in addition to increase yield also increased $\mathrm{N}$ absorbent. Increased of $\mathrm{N}$ absorbent elements and the fulfillment of water availability in root areas, instigating vegetative growth of Salak plants indicated by the increase of new midrib will take place optimally and continuously. The continuous growth of new midrib continues to instigate the growth of the flower, remembering that the emergence of Salak spray along with the emergence of new midrib. Kaat et al. (1999) reported that $\mathrm{N}$ fertilization in urea form dose of $0.5 \mathrm{~kg}-1.5 \mathrm{~kg}$ per tree in Khina-1 hybrid coconut plant, in addition to increase vegetative growth, stem height, midrib and midrib leaves and fruit.

The interaction between water supply and ZA fertilization has an effect on the result of Salak Suwaru, therefore fruit weight per cluster. The interaction between 20 days water interval and ZA fertilization on $300 \mathrm{~g}$ dosage per tree resulted in the greatest fruit weight per cluster of $2.70 \mathrm{~kg}$ (Table 3).

Table 3 - The Interaction effect between water delivery and ZA fertilization on Salak suwaru fruit weight per cluster

\begin{tabular}{lcccc}
\hline & \multicolumn{4}{c}{ Fruit weight per cluster $(\mathrm{kg})$} \\
\cline { 2 - 5 } \multicolumn{1}{c}{ Treatment } & ZA fertilizer & ZA fertilizer & ZA fertilizer & ZA fertilizer \\
& dose $(\mathrm{g} /$ tree $)$ & dose $(\mathrm{g} /$ tree $)$ & dose $(\mathrm{g} /$ tree $)$ & $\begin{array}{c}\text { dose }(\mathrm{g} / \text { tree }) \\
\end{array}$ \\
& 0 & 100 & 200 & 300 \\
\hline Without water supply & $1,11 \mathrm{a}$ & $1,56 \mathrm{~b}$ & $1,69 \mathrm{c}$ & $1,85 \mathrm{~d}$ \\
20 days interval water provision & $1,81 \mathrm{~d}$ & $2,04 \mathrm{e}$ & $2,36 \mathrm{f}$ & $2,70 \mathrm{~g}$ \\
\hline
\end{tabular}

Note: Numbers on the same columns and rows completed by different letters show a marked difference based on the BNT test at the 5\%.

In Table 3 shows that Salak Suwaru plants without water supply, the production (fruit weight per cluster) is constantly lower compared to the irrigated Salak plant's production. The higher ZA fertilizer doses, the better fruit weight per cluster, for both irrigated and nonirrigated Salak plants. These results are in line with Neilsen et al. (1989) which stated that irrigation in young apple crops increases production and the number of fruits per tree is $12 \%$ and $39 \%$, respectively. Kaat et al. (1999) reported that increasing the doses of $\mathrm{N} 0,5 \mathrm{~kg}$ per tree also increases the yield of Khina- 1 hybrid coconut by $25 \%$.

Environmental factors grow, especially ground water conditions and soil fertility (availability of elements of $\mathrm{N}$ and $\mathrm{S}$ ) is fairly influential on Salak plant's generative growth. This indicates that water supply and ZA fertilization in Salak Suwaru plants in addition to increase the number of flowers also increase improves the fruit weight production per cluster. 
This fact is in line with Sudaryono et al. (2000) who reported that fertilization of $300 \mathrm{~g} \mathrm{ZA}$ fertilization followed by $37.5 \mathrm{~g}$ Urea $+175 \mathrm{~g}$ Potassium Chloride $+200 \mathrm{~g}$ Dolomite $+3.75 \mathrm{~g}$ Borax $+3.75 \mathrm{~g}$ Zinc Sulfate per tree and 20 days interval irrigation (during the dry season) increased the number of flower clusters, the number of fruit clusters and the production of Salak gradually $74 \%, 81 \%$ and $84 \%$.

The increased production of Salak Suwaru seems instigated also by the increasing of nutrient absorbent $S$ by Salak plants, given ZA contains nutrient $S$ by $22 \%$. If prior to $Z A$ fertilization S levels in leaves only $0.82 \%$; after ZA fertilization dose of $100 \mathrm{~g}, 200 \mathrm{~g}$ and 300 g per tree, $S$ levels grew to $0.94 \%, 1.15 \%$ and $1.28 \%$, respectively.

The Influence of Water Delivery and ZA Fertilization on Salak Suwaru farmers' Income. The Efforts to increase Salak Suwaru off-season production needs to be done. Salak Suwaru off-season production will increase farmers' income, because the selling price can reach 3 times compared to the common selling price during the harvest period (Kasijadi, 1994). Water supply and ZA fertilization in addition to increase Salak Suwaru production also increased the harvest season (off season) which occurred in April - May, which in additional harvest season is obtained additional Income of Rp 6,020, - per tree (Table 4). This fact is in line with Sudaryono et al. (1999) which suggested that Suwaru seasonal harvest season in the external season can occur in March - May or August - October. Assuming that each hectare consists of 1600 Salak trees, water supply and ZA fertilization will generate Salak Suwaru farm income by $R p 30.160 .000$, - / ha / year. This income is almost three times greater than without water supply and ZA fertilization in which only reached Rp 11.680.000, / ha / year. The increase of Salak Suwaru farming income due to water supply and ZA fertilization, besides due to the increase of production in every harvest season both at harvest and apitan, also caused by the harvest in the off-season which gives additional income of farming Rp 9.632.000, -.

Table 4 - The Effect of water supply and ZA fertilization on the production, output, input and income of Salak Suwaru farm at highway harvest, apitan and off-season harvest

\begin{tabular}{|c|c|c|c|c|c|c|c|c|c|c|c|c|}
\hline \multirow[b]{2}{*}{ Treatment } & \multicolumn{4}{|c|}{$\begin{array}{c}\text { Highway Harvest } \\
\text { (December-January) }\end{array}$} & \multicolumn{4}{|c|}{$\begin{array}{c}\text { Apitan Harvest } \\
\text { (July-August) }\end{array}$} & \multicolumn{4}{|c|}{$\begin{array}{c}\text { Off-season Harvest } \\
\text { (April-May) }\end{array}$} \\
\hline & $\begin{array}{l}\text { Prod } \\
(\mathrm{kg})\end{array}$ & $\begin{array}{l}\text { Out- } \\
\text { put }^{1} \\
\text { (Rp) }\end{array}$ & $\begin{array}{l}\text { Input } \\
\text { (Rp) }\end{array}$ & $\begin{array}{l}\text { Income } \\
\text { (Rp) }\end{array}$ & $\begin{array}{c}\text { Prod } \\
(\mathrm{kg})\end{array}$ & $\begin{array}{l}\text { Out- } \\
\text { put }^{2} \\
\text { (Rp) }\end{array}$ & $\begin{array}{l}\text { Input } \\
\text { (Rp) }\end{array}$ & $\begin{array}{l}\text { Income } \\
\text { (Rp) }\end{array}$ & $\begin{array}{l}\text { Prod } \\
(\mathrm{kg})\end{array}$ & $\begin{array}{l}\text { Out- } \\
\text { put }^{3} \\
\text { (Rp) }\end{array}$ & $\begin{array}{c}\text { Input } \\
\text { (Rp) }\end{array}$ & $\begin{array}{l}\text { Income } \\
\text { (Rp) }\end{array}$ \\
\hline Control & 1,10 & 3.300 & 0 & 3.300 & 0,80 & 4.000 & 0 & 4.000 & 0 & 0 & 0 & 0 \\
\hline $\begin{array}{l}\text { Irrigation } \\
+ \text { ZA } \\
\text { fertilizer }\end{array}$ & 2,23 & 6.690 & 1.180 & 5.510 & 1,70 & 8.500 & 1.180 & 7.320 & 1,20 & 7.200 & 1.180 & 6.020 \\
\hline
\end{tabular}

Note:

1) Fruit price per kg $\operatorname{Rp} 3.000,-$

2) Fruit price per kg Rp 5.000,-

Input $=$ Input $=$ Fertilizer and water price

3) Fruit price per kg Rp 7.000,Output $=$ Production $x$ fruit price Income = Output-Input

\section{CONCLUSION}

Increasing the production and income of Salak Suwaru farming can be obtained through water supply and ZA fertilization. Water provision and ZA fertilization can increase Salak Suwaru production up to two-fold and farming income up to three times.

\section{REFERENCES}

1. Chapman, S. R and L. P. Carter. 1976. Crop production, principles and practices. W. H. Freeman and Company, San Fransisco.

2. Department of Agriculture Food Crops Level II Region Malang Regency. 1997. Salak Suwaru.

3. Felizardo, B. C. 1983. Coconut research improvement in Indonesia. Report of consultan on Fertility. Ins/31/015. 
4. Gardner, F., P. Pearce and R. L. Michele. 1985. Physiology of crop plant. The lowa State University Press.

5. Kaat, H., R. Rachman dan D. Allorerung. 1999. Pengaruh pemupukan terhadap pertumbuhan dan produksi kelapa hibrida Khina-1 pada tanah podzolik. Buletin Palma No. $25: 46-54$.

6. Regional Office of the Department of Agriculture of the First Level Region of East Java Province. 1999. Laporan pertemuan pembinaan manajemen Kopaku/Kuba di Kabupaten Malang.

7. Kasijadi, F. 1994. Analisis efisiensi usahatani salak kultivar Suwaru di Jawa Timur. Penel. Hort. 6(3) : 83-89.

8. Lestari, R and G. Ebert. 2002. Salak-the Indonesian snake fruit. Hamboldt Uiversity Berlin, Departement of fruit production. Berlin, Germany.

9. Mogea, J. P. 1984. Three new species of genus salacca (Palmae) from the Malay Peninsula. Museum J. $29: 1-22$.

10. Neilsen, G. H., D. S. Stevenson, J. J. Fitzpatrick and C. H. Brownlee. 1989. Nutrition and yield of young apple tree irigated with muncipal waste water. J. Amer. Soc. Hort. Sci. 114 (3) : 377-383.

11. Neithsinghe, D. A. 1962. Coconut nutrition and fertilizer requirement the soil approach. Indian Coconut $\mathrm{J}$.

12. Ridley, H. N. 1925. The flora of Malay Peninsula. Vol. V. L. Reeve \& Co, Ltd. London

13. Schuiling, D. L and J. P. Mogea. 1992. Salacca zalacca (Gaertner) Voss. p. 281-284. In: Verheij, E. W. M and R. E. Coronel (eds.). Plant resources of South Esat 2 : Edible Fruit and nuts. Pudoc/Prosea, Wageningen.

14. Soleh, M, Suhardjo dan A. Suryadi. 1995. Pengaruh pemberian air dan masukan hara makro serta mikro terhadap produksi salak. Sub Balai Penelitian Hortikultura, Malang.

15. Sudaryono, T, S. Purnomo dan M. Soleh. 1993. Distribusi varietas dan perkiraan wilayah pengembangan salak. Penel. Hort. 5(2) : 1-4.

16. Sudaryono, T., L. Rosmahani, A. Suryadi, Q. D. Ernawanto dan E. Srihastuti. 1999. Perakitan teknologi peningkatan frekuensi panen salak unggulan Jawa Timur. p. 122128. In: Roesmiyanto, Komarudin-Maksum, P. Santoso, M. E. Dwiastuti dan H. Sembiring (eds.). Prosiding Seminar Hasil Penelitian/Pengkajian. BPTP Karangploso, Malang.

17. Sudaryono, T., A. Suryadi dan L. Rosmahani. 2000. Teknologi peningkatan frukuensi panen salak unggulan Jawa Timur. p. 211 - 214. In : Musofie, A., N. K. Wardhani, D. Shiddieq, Suharto, R. Mudjisihono, Aliudin, B. Hutabarat (eds.). Prosiding Seminar Teknologi Pertanian Spesifik Lokasi dalam Upaya Peningkatan Kesejahteraan Petani Dan Pelestarian Lingkungan. Pusat Penelitian Sosial Ekonomi Pertanian, Bogor.

18. Sumarno. 2004. Potensi dan peluang usaha agribisnis buah tropika dalam era pasar bebas. p. 1-14 In : Roesmijanto, A. Djauhari, S. Yuniastuti, R. Hardianto, P. E. R. Prahardini (eds.). Prosiding Seminar Prospek Sub-Sektor Pertanian Menghadapi Era AFTA Tahun 2003. Badang Litbang Pertanian, Puslitbang Sosial Ekonomi Pertanian, Bogor.

19. Widyastuti, Y. E. Dan F. R. Paiman. 1993. Mengenal buah unggul Indonesia. PT Penebar Swadaya, Jakarta.

20. Wijadi, R. D., E. Sugiharti dan Martono. 2000. Pengkajian teknologi pengelolaan tanaman induk salak. p. 326-331. In : Soetjipto, P. H., M. C. Mahfud, M. A. Yusron (eds.). Prosiding Seminar Hasil Penelitian/Pengkajian Teknologi Pertanian Mendukung Ketahanan Pangan Berwawasan Agribisnis. Badan Litbang Pertanian, Puslitbang Sosial Ekonomi Pertanian, Bogor. 